\title{
AN UPDATE ON HONG KONG'S EXCHANGE OF INFORMATION DEVELOPMENTS AND ENGAGING WITH BEPS
}

\author{
Adrian Sawyer*
}

\begin{abstract}
The Hong Kong Special Administrative Region (HKSAR) implemented automatic exchange of information (AEOI) with the Inland Revenue (Amendment) (No. 3) Ordinance 2016 coming into effect on 30 June 2016. This development is one of the latest phases in the reform of the HKSAR's exchange of information capability, and is an important issue as AEOI 'challenges' the HKSAR's approach to privacy of information. AEOI follows earlier legislative reform to permit the HKSAR to enter into tax information exchange agreements (TIEAs), and the signing of a Model 2 intergovernmental agreement (IGA) under the United States' (US's) Foreign Account Tax Compliance Act (FATCA). The HKSAR has been actively engaged in the G20/OECD's Base Erosion and Profit Shifting (BEPS) initiative, particularly as an Associate member that has enabled it to facilitate implementation of the relevant BEPS Action Plans in both the HKSAR and internationally. Collectively AEOI and BEPS have 'opened up' the HKSAR to greater international scrutiny and will introduce greater complexity into the HKSAR's tax system. This paper briefly reviews the historical developments in information exchange in the HKSAR, focussing on the implications of AOEI and BEPS developments for the HKSAR, with some preliminary thoughts as to what the future may look like for businesses operating in the HKSAR.
\end{abstract}

\subsection{Introduction and Background}

The last four years have produced unprecedented advances in tax transparency and exchange of information in the Hong Kong Special Administrative Region (HKSAR). This commenced when the

\footnotetext{
* Dr Adrian Sawyer is Professor of Taxation, and Research Director for the School of Business and Economics, at the University of Canterbury, Private Bag 4800, Christchurch, NZ. Email: adrian.sawyer@canterbury.ac.nz. This paper draws upon earlier work by the author while he was a visitor hosted by the Asian Institute of International Financial Law (AIIFL) and Taxation Law Research Programme (TLRP) at the University of Hong; see further: Adrian Sawyer, "Charting the Future: How is Hong Kong Responding to International Pressure for Enhanced Transparency, Cooperation and Information Exchange on Taxation Matters?", (2013) 17(1) Asia Pacific Journal of Taxation, 56-66; and Adrian Sawyer, "Will Hong Kong Succumb to International Pressures on Taxation Matters?", (2014) 22(2) Asia Pacific Law Review, 3-32. It also builds upon a more recent update by the author published in 2015; see Adrian Sawyer, "Hong Kong Continues to Enhance its Information Exchange on Taxation Matters - A Stocktake", (2015) 19(2) Asia Pacific Journal of Taxation, 26-36. An earlier version of this paper was presented at a seminar organised by the AIIFL and TLRP in November 2016; I would like to thank both AIIFL and TLRP for their ongoing support with this research, and the reviewers for their helpful comments that have improved the paper. This paper sets out the state of play as at midOctober July 2017 and is based upon publicly available information.
} 
Global Forum for Transparency and Exchange of Information for Tax Purposes (Global Forum) ${ }^{1}$ released its Phase Two Peer Review Report on the HKSAR in November 2013. ${ }^{2}$ This report signalled that the HKSAR was largely compliant with its domestic law and regulations with respect to facilitating tax transparency and exchange of information (in a pre-automatic exchange of information (AEOI) environment). Furthermore, following the enactment of the Inland Revenue (Amendment) (No 2) Ordinance 2013 (the Ordinance) on 10 July 2013, the HKSAR has been able to enter into tax information exchange agreements (TIEAs); most significantly, the first TIEA was with the United States (US). Six further TIEAs were signed in August 2014 with: Denmark; Faroes Islands; Greenland; Iceland; Norway; and Sweden. ${ }^{3}$

Another significant event for the HKSAR was concluding an in substance Model 2 intergovernmental agreement (IGA) under the US's Foreign Account Tax Compliance Act (FATCA) which took effect in time for the 1 July 2014 implementation date of FATCA. ${ }^{4}$ This was followed up by the HKSAR signing a final Model 2 IGA later in 2014. The writer would argue that the influence of the People's Republic of China (PRC) is clear with respect to the decision by the HKSAR to negotiate an IGA under FATCA, and to maintain ongoing negotiations to modify its comprehensive double tax agreement (CDTA) with the People's Republic of China (PRC). TIEAs and CDTAs have continued to be negotiated by the HKSAR.

The HKSAR spent a short period on the European Union's (EU's) blacklist of third country noncooperative tax jurisdictions. ${ }^{5}$ Conclusion of the Model 2 IGA would have assisted the HKSAR in being removed from the EU's blacklist of non-cooperative jurisdictions in October 2015.

In relation to the OECD's Base Erosion Profit Shifting (BEPS) Action Plans, the HKSAR has been a follower, and determined that, following a period of consultation, it will put in place an AEOI facility. An Amendment Bill introduced in early 2016 for consideration by the Legislative Council (LegCo) was subsequently became law as from 30 June 2016. With respect to the wider BEPS initiatives, the HKSAR announced on 20 June 2016 that it would be fully embracing implementation of BEPS when it became an Associate member. This required the HKSAR to review its current state

\footnotetext{
${ }^{1}$ See further http://www.oecd.org/tax/transparency/.

${ }^{2}$ OECD (2013), Global Forum for Transparency and Exchange of Information for Tax Purposes: Phase Two: Hong Kong, China 2013 (OECD, Paris).

${ }^{3}$ See http://www.ird.gov.hk/eng/tax/dta_tiea_agreement.htm. Negotiations are underway for a concluding a TIEA with Argentina, the Philippines and Poland.

${ }^{4}$ Pub. L. No. 111-147, 124 Stat 71 (March 18, 2010). FATCA comprises sections 1471 to 1474 of the Internal Revenue Code 1986.

${ }^{5}$ Financial Services and Treasury Bureau (FSTB), "Press Release: Hong Kong's tax co-operation status clarified by EC" (October 14, 2015), available at: http://www.fstb.gov.hk/tb/en/docs/pr_20151014_e.pdf.
} 
of preparedness to meet BEPS expectations. Since then the HKSAR has further facilitated AEOI by increasing the number of reportable jurisdictions, and is proposing to empower the Chief Executive to give effect to a number of international tax agreements.

The remainder of this paper is organised as follows. The next section provides a brief overview and critical analysis of recent international developments and their potential implications with respect to AEOI in the HKSAR. Section 3 then overviews other developments in the international tax area, focussing on the HKSAR's engagement in the BEPS implementation process, before section 4 sets out the concluding observations from the earlier discussion.

\subsection{Developments in automatic exchange of information in the HKSAR}

In late 2014, the HKSAR Government indicated to the Global Forum that it intended to support the new standard of AEOI. The Panel on Financial Affairs (Panel) reported to LegCo that Panel members had exchanged views with the HKSAR Administration on a number of issues including: ${ }^{6}$

- the benefits of AEOI and compliance costs,

- consistency of reporting standard for local and overseas financial institutions, and

- $\quad$ safeguards to protect privacy and confidentiality of information exchanged.

As a consequence of the increasing aspirations of the international community for AEOI (reflected in more than 90 Global Forum members at that time expressing their commitment to AEOI), it was considered necessary for the HKSAR to put in place the required legal framework to enable AEOI. The risk of not doing so was that the HKSAR could be labelled as an uncooperative jurisdiction or a 'tax haven'. Such a label would undermine its position and competitiveness as an international business and financial centre.

Moving both sideways and forward to mid-2015, the European Union (EU) placed the HKSAR on its blacklist of 30 non-cooperative jurisdictions. This list included many of the well-known tax havens which is largely unsurprising. Soon after the release of the blacklist, the HKSAR Government expressed its regret over this decision by the EU, pointing out how the HKSAR has been cooperative and supportive of international efforts on EOI and transparency. Subsequently, on 14 October 2015, the HKSAR Government was able to advise that the EU had removed the HKSAR from its blacklist,

${ }^{6}$ Legislative Council, Report of the Panel on Financial Affairs for submission to the Legislative Council (November 2014), LC paper No. CB(1)000/14-15; available at: http://www.legco.gov.hk/yr1415/english/panels/fa/reports/fa20150624cb1-999-e.pdf. 
although some member EU states retained the HKSAR on their own blacklists. In particular, the HKSAR's Financial Services and Treasury Bureau (FSTB) acknowledged that: ${ }^{7}$

"The Government would like to express its gratitude to many stakeholders in the business community for their assistance in helping refute the unfounded allegation against Hong Kong as a tax haven, and in putting across a correct message on Hong Kong's position on tax cooperation."

Big four accounting firm PWC commented that the HKSAR will maintain an ongoing dialogue with the EU over it efforts regarding cooperation, will continue with drafting its response to AEOI, and continue to expand its network of CDTAs. ${ }^{8}$

Returning now to the matter of AEOI. The HKSAR's Financial Services and the Treasury ('the FST') had recommended in 2013 that the existing Inland Revenue Ordinance (IRO) should be amended and that there are no other options available than to provide for enhanced EOI. ${ }^{9}$ In effect, this was an admission of the HKSAR being 'backed into a corner' with the only exit being greater cooperation, transparency and information exchange. There was genuine concern over the consequences for the HKSAR should it not engage with the OECD and Global Forum with respect to AEOI, something which the writer has discussed in detail previously. ${ }^{10}$

In the light of this pressure, on 24 April 2014, the HKSAR Government launched its consultation process on AEOI with the release of a comprehensive consultative document. This followed a brief period of engaging with stakeholders in the financial industry to assess their initial views on how AEOI should be implemented in the HKSAR. Professor K C Chan, the Secretary for the FSTB, stated in his media release: ${ }^{11}$

"Hong Kong will adopt a pragmatic approach to legislate for all essential requirements of the OECD standard on AEOI, and will ensure effective implementation of the new standard. ... Our plan is to conduct AEOI on a bilateral basis with jurisdictions with which Hong Kong has signed a comprehensive avoidance of double taxation agreement (CDTA) or a Tax Information Exchange Agreement (TIEA). In identifying AEOI partners from amongst our CDTA or TIEA

\footnotetext{
${ }^{7}$ See note 5.

8 PWC, “Applause for Hong Kong's removal from the EU’s blacklist” (2015) Hong Kong Tax No 9 (October).

${ }^{9}$ Legislative Council, Brief: Inland Revenue Ordinance (LegCo, the HKSAR, 2013), para 18.

${ }^{10}$ See Adrian Sawyer, "Will Hong Kong Succumb to International Pressures on Taxation Matters?" (2014) 22(2) Asia Pacific Law Review, 3-32.

${ }^{11}$ Inland Revenue Department (HK), "Consultation on Automatic Exchange of Financial Account Information in Tax Matters in HK launched" (April 24, 2014); available at: http://www.ird.gov.hk/eng/ppr/archives/15042401.htm. The consultation document is available at: http://www.fstb.gov.hk/tb/en/docs/AEOI-ConsultationPaper-e.pdf.
} 
partners, we will take into account their capability in meeting the OECD standard and in protecting data privacy and confidentiality of the information exchanged in their domestic law."

Annex $\mathrm{C}$ to the consultation document set out the proposed (and subsequently enacted) framework for AEOI in the HKSAR. It is reproduced below: ${ }^{12}$ 
Annex C

Schematic Framework for AEOI Legislation in Hong Kong

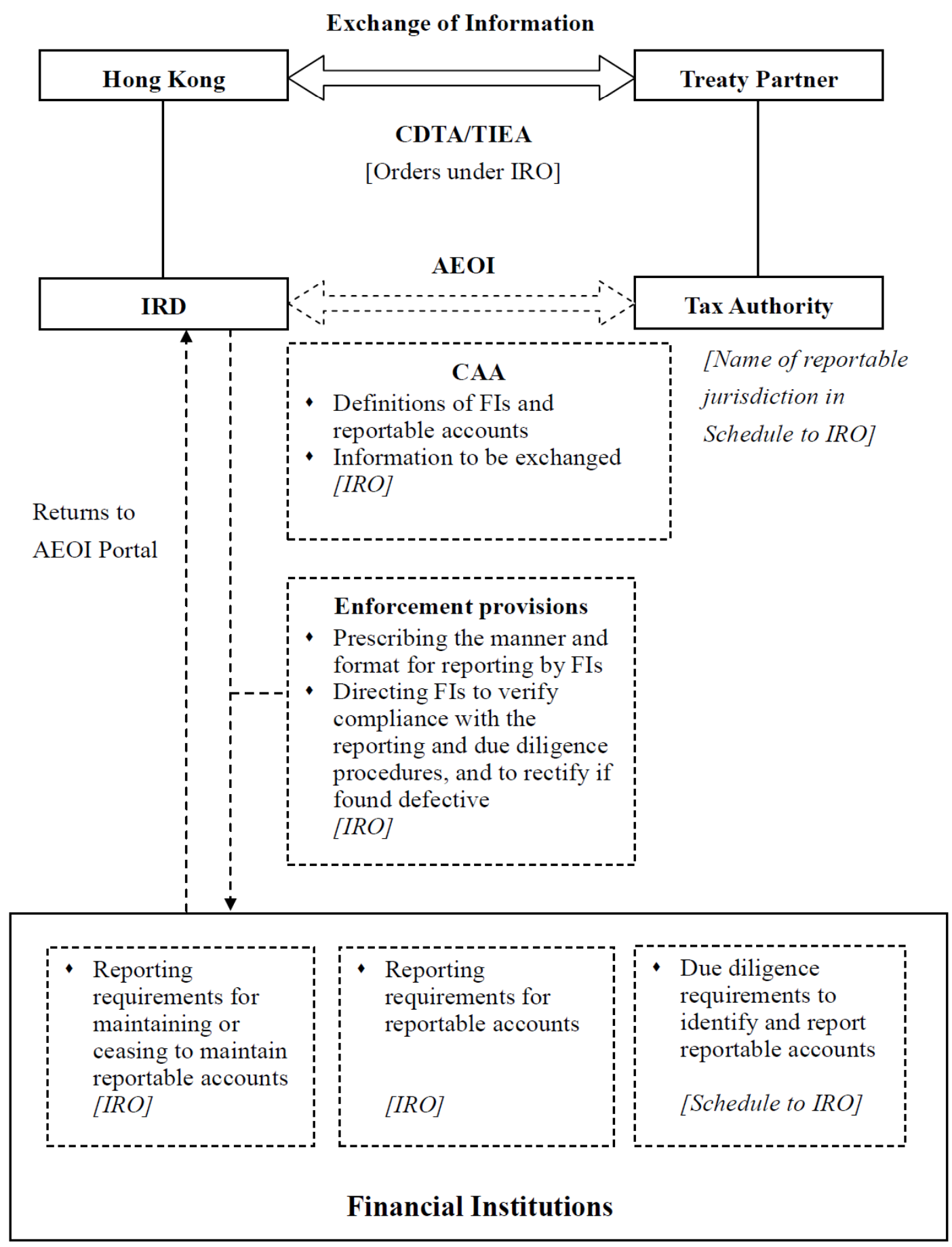

The AEOI standard developed by the OECD and the Global Forum was heavily influenced by the US's FATCA approach. As a result, Big Four accounting firm EY observes: ${ }^{13}$

${ }^{13}$ EY, "Hong Kong joins the drive for the automatic exchange of information" (2014) Global Tax Alert (November), at 2. 
“... financial institutions are expected to be able to leverage and build upon their institutional arrangements already initiated for compliance with FATCA in order to meet the reporting requirements of implementing AEOI."

The Panel reviewing the AEOI proposal released its feedback on the 40 submissions it received on the AEOI consultation document in July 2015. ${ }^{14}$ Specifically the Panel recommended that legislative changes are introduced that provide for:

a) definitions of financial institutions (FIs) and reportable accounts;

b) exemptions in the form of non-reporting FIs and excluded accounts;

c) reportable account information, including personal data and financial data of non-Hong Kong tax resident account holders;

d) powers of IRD to collect and access to information from financial institutions; and

e) sanctions for financial institutions for non-compliance and account holders for false selfcertification.

The HKSAR Government accepted the recommendations, and in its media release of 12 October 2015, indicated that it would be targeting early 2016 to introduce a bill into LegCo. The media release was accompanied by the HKSAR Government's consolidated response to the proposals for AEOI. ${ }^{15}$

The Inland Revenue (Amendment) (No. 3) Ordinance 2016 (the Amendment Bill) was gazetted on 8 January 2016, and had its first reading in a LegCo meeting on 20 January 2016. The main proposals echo the recommended changes by the Panel as set out above. Accompanying the Amendment Bill was a background brief prepared by the LegCo Secretariat on 1 February 2016. ${ }^{16}$ Submissions were received on the Amendment Bill, ${ }^{17}$ including from the HKICPA, which suggested that there be a

14 Legislative Council, Automatic Exchange of Financial Account Information in Tax Matters (6 July 2015), CB(1)1034/14-15(06); available at: http://www.legco.gov.hk/yr14-15/english/panels/fa/papers/fa20150706cb1-1034-6e.pdf.

${ }^{15}$ Financial Services and Treasury Bureau, Consultation on Automatic Exchange of Financial Account Information in Tax Matters (“AEOI”) (October 2015); available at: http://www.fstb.gov.hk/tb/en/docs/consolidated-response.pdf.

${ }^{16}$ Legislative Council Secretariat, Bills Committee on Inland Revenue (Amendment) Bill 2016: Background Paper (2016) LC paper No. CB(1)518/15-16(03).

${ }^{17}$ Submissions were received from: Asia Securities Industry \& Financial Markets Association; Hong Kong Institute of Certified Public Accountants; Hong Kong Investment Funds Association; Hong Kong Trustees' Association; International Chamber of Commerce - Hong Kong, China; The Association of Hong Kong Accountants; The Chinese General Chamber of Commerce; The Hong Kong Association of Banks; The Hong Kong Federation of Insurers; The Institute of Certified Management Accountants (Hong Kong Branch); and STEP Hong Kong Ltd. 
mechanism for account holders to apply to financial institutions and to the HK IRD to get access to and the opportunity to correct their personal data. In line with the Personal Data (Privacy) Ordinance, financial institutions must ensure that the personal data they hold is accurate and allow account holders to review and correct their personal and financial data. No further specific checks will be put in place. ${ }^{18}$

The FSTB reported back on the submissions received on the Amendment Bill in March 2016. Most submitters supported and agreed with the HKSAR's pragmatic policy approach to implementing AEOI. ${ }^{19}$ Reciprocity is seen as a key principle upon which the AEOI framework is based. The FSTB agreed to draw up the relevant guidelines for reporting and due diligence (as set out in Schedule 17D to the Amendment Bill) once the Amendment Bill was enacted. It would also keep close contact with the relevant industry when doing this. Low risk financial institutions and excluded accounts were added to Schedule 17C of the Amendment Bill. Sufficient safeguard measures were considered by the FSTB to be in place without the need for any further additions.

The Bills Committee reported back on the Amendment Bill in May 2016. Their report is extensive, indicating that a number of issues were discussed, including whether the HKSAR must fully commit to and implement AEOI (especially since the US has yet to fully commit to it), and safeguards for privacy. Notwithstanding the tenor of the discussion, the Bills Committee and the Administration did not recommend any Committee Stage Amendments (CSA). The Amendment Bill was enacted with effect from 30 June 2016.

Further details on the HK IRD's interpretation and practice with respect to exchange of information is available in its DIPN 47 (revised), the latest version current as at January 2014. ${ }^{20}$ This practice statement will no doubt need to be revised further once AEOI is fully operational to ensure the HKSAR Inland Revenue Department's (HK IRD's) practice is in accord with the amendments to the Inland Revenue Ordinance.

The preceding discussion has been largely descriptive in illustrating the cautious approach by which the HKSAR has engaged with AEOI. The HKSAR's approach is justified given the need to balance enhanced exchange of information with taxpayer privacy concerns and increased complexity being added to the HKSAR's tax system. Should the HKSAR have instead decided to take a calculated

\footnotetext{
18 See further Financial Services and the Treasury Bureau, Response to further comments raised by the Hong Kong Institute of Certified Public Accountants ("HKICPA") (May 2016).

${ }^{19}$ Financial Services and the Treasury Bureau, Bills Committee on Inland Revenue (Amendment) Bill 2016: Follow up to the meeting on 1 March 2016 (March 2016).

${ }^{20}$ Inland Revenue Department Hong Kong, Exchange of Information” (2014) DIPN (47) Revised.
} 
risk to not engage and legislate for AEOI, it would have placed itself at risk of being labelled an uncooperative jurisdiction, with a potential consequence of losing its position as a major financial centre. This risk, in my view, would have been one too great to take, and as such the HKSAR was justified in legislating for AEOI. In meeting the 'minimum standards' this enables the HKSAR to preserve as far as practically possible its desire to protect taxpayer privacy and retain a relatively simple tax system.

Nevertheless, major implications of AEOI with respect to the HKSAR's tax system are the challenges to its position on taxpayer privacy, retaining a relatively simple tax system, and maintaining its position as a highly desirable financial centre. In some respects these challenges go to the heart of what has made the HKSAR's tax system the envy of many other jurisdictions, especially given that it generates significant fiscal surpluses. If the only challenges were to come from AEOI, then arguably this would not been seen as a particularly significant development internationally (although it remains significant for the HKSAR). The speed of implementation, along with other more significant developments, including BEPS, 'raise the stakes'.

As a consequence of the tight timeframe for AEOI, the commitment by the HKSAR to commence its first AEOI was made for no later than by the end of 2018. ${ }^{21}$ Consequently, the HKSAR will not be an early adopter of AEOI but would be joining over 100 jurisdictions that have committed to AEOI through use of the Common Reporting Standard (CRS) and Country by Country Reporting (CbCR).

The CRS requires financial institutions to perform due diligence procedures and to transmit systematically financial data from their non-resident customers. The type of information and the due diligence to put in place for all financial accounts are defined by the CRS, and include: interest, dividends, account balances or values, income from certain insurance products, sales proceeds from financial assets and other income generated with respect to assets held in the account or payments made with respect to an account. ${ }^{22}$ The financial institutions involved include: custodial institutions, depository institutions, investment entities and specified insurance companies. The HKSAR IRD will act as the competent authority for the HKSAR.

The HKSAR's timeline for collecting and reporting information is set out below:

${ }^{21}$ See Inland Revenue Department (HK), Government committed to timely implementation of AEOI in Hong Kong (October 12, 2015); available at: http:/www.ird.gov.hk/eng/ppr/archives/15101201.htm.

${ }^{22}$ See further: http://www.ird.gov.hk/eng/pdf/2016/aeoi_pam3.pdf. 
- January 2017: data capture begins by identifying financial accounts held by residents of the reportable jurisdiction (those that the HKSAR has a signed competent authority agreement with concerning AEOI);

- Mid-2018: financial institutions transmit data to the tax authority of their jurisdiction for calendar year 2017;

- September 2018: this data is then transmitted to the tax authorities of the relevant jurisdictions that the HKSAR has a signed competent authority agreement with concerning AEOI;

- From 2019 going forward: identify and transmit reportable accounts on a regular basis.

The HKSAR will require a new Schedule to be included in the Inland Revenue Ordinance by the end of 2016 to facilitate this aspect of AEOI. A key issue with AEOI is determining tax residence. Tax residence will be determined through the normal tests of a person's physical presence or time spent in a particular place (the 183 day within a tax year rule). For a company the usual tests of the place of incorporation or whether the centre of management and control is located, will be applied. ${ }^{23}$

In most cases, self-certification, as set out by the international standard for AEOI, is to be applied by account holders. $^{24}$ To assist FIs to meet their AEOI obligations, the HK IRD has added links on its website to details of the relevant legislation, and to guidance for FIs, including the IRD's views on the due diligence procedures required by the OECD's CbCR requirements. ${ }^{25}$

As at the time of writing, the HKSAR has a CDTA or TIEA in place with 45 jurisdictions, and will identify those jurisdictions within this group that have appropriate AEOI procedures in place, for the HKSAR to determine to be its targeted AEOI partners. The HKSAR has expand this network of CDTAs and TIEAs during 2016-17, having three TIEAs under negotiation at the time of writing this paper. Two further CDTAs have been concluded, namely with Belarus in January 2017 and with Latvia in April 2016; both have yet to come into force. Thirteen further CDTAs are under negotiation. On 24 January 2017, the HKSAR IRD confirmed that the HKSAR has signed an agreement with Korea with a view to commencing the automatic exchange of financial account information in tax matters (AEOI) in 2019. Two earlier agreements were signed in with Japan and

\footnotetext{
${ }^{23}$ As the HKSAR uses a territorial-based tax system, the issue of residents $v$ non-residents become principally an issue with respect to cross-border transactions - the CDTAs and TIEAs operate in this regard.

${ }^{24}$ See further the OECD's AEOI portal: http://www.oecd.org/tax/automatic-exchange/.

${ }^{25}$ See further: http://www.ird.gov.hk/eng/tax/dta_aeoi.htm.
} 
the United Kingdom (UK) in late $2016 .{ }^{26}$ One notable exception is that there are no negotiations between the HKSAR and Australia to enter into a TIEA. However, it appears that Australia and Hong Kong may be willing to enter negotiations for a DTA. ${ }^{27}$ While in Canberra, the HKSAR's Secretary for FSTB, K C Chan, expressed his wish to quickly start negotiations on a comprehensive double taxation agreement with Australia. ${ }^{28}$ Collectively this provides strong evidence of the HKSAR's desire to build an extensive treaty network in order to facilitate exchange of information.

The overarching focus for the HKSAR, it appears, is to do all that it can within these constraints to ensure that it protects the confidentiality of information of taxpayers where this information is held within the HKSAR. This is understandable given the importance of confidentiality of information generally in the HKSAR. One area where the HKSAR is expected to face some difficulty is with respect to companies and their cross border operations and transactions, with the need for increased disclosure of information and increased pressure to exchange tax information. In particular, the OECD's BEPS Action Plan 13, which is concerned with transfer pricing expectations, will provide challenges for the HKSAR. The relatively low level public response by the HKSAR to BEPS developments, was until June 2016 at least, in contrast to other jurisdictions that are not at the forefront of BEPS (or members of the G20), such as New Zealand. ${ }^{29}$ This has since increased with the enactment of Inland Revenue (Amendment) (No. 2) Ordinance 2017 which came into operation on 1 July 2017. This particular Amendment Ordinance amends the definition of 'reportable jurisdiction' so that reportable jurisdictions can include territories outside the HKSAR irrespective of whether they are parties to arrangements having effect under section 49(1A) of the Inland Revenue Ordinance and requiring disclosure of information concerning tax of the territories. It also adds 73 jurisdictions to the list of reportable jurisdictions (in addition to the two jurisdictions already included in the current list). ${ }^{30}$ This enactment is designed to ensure that the HKSAR can gather financial account information from the second half of 2017 for exchanging with these other

\footnotetext{
${ }^{26}$ See further: http://www.ird.gov.hk/eng/ppr/archives/17012401.htm.

${ }^{27}$ See comments made by Prof Nolan Sharkey, "Having been up in the air for a number of years, it has now been announced that Hong Kong and Australia are actually looking at a DTA. I say "up in the air" as, in some ways, the DTA is overdue." Available at: https:/www.linkedin.com/pulse/what-difference-hong-kong-australia-double-tax-make-looksharkey-fca.

${ }^{28}$ See http://www.treatypro.com/treaties_by_country/australia.asp.

29 See Adrian Sawyer, "New Zealand: Update on BEPS and FATCA" (2015) 17(4) Derivatives and Financial Instruments (9 July) online.

${ }^{30}$ See Inland Revenue (Amendment) (No. 2) Ordinance 2017. The jurisdictions include 13 confirmed AEOI partners and 62 prospective AEOI partners. The 62 prospective AEOI partners include the following three categories:
}

(1) jurisdictions which have expressed an interest in conducting AEOI with Hong Kong to the OECD or jurisdictions suggested by the OECD;

(2) Hong Kong's tax treaty partners which have committed to AEOI; and

(3) all member states of the EU. 
jurisdictions that should minimise the compliance burden to financial institutions. To the end of September 2017, the HKSAR has signed agreements with 14 jurisdictions to facilitate AEOI on a bilateral basis.

Importantly, the HKSAR government has advised that it would only conduct AEOI with jurisdictions which have signed dedicated exchange agreements with the HKSAR and have fulfilled the OECD's standard and relevant safeguards for protecting data privacy and confidentiality of the information exchanged. For example, if a person is not a tax resident of any jurisdictions outside the HKSAR, then financial institutions in the HKSAR will not report this information to the HKIRD under this regime. ${ }^{31}$ Thus in terms of AEOI, the HKSAR is now in a position to meet the expectations placed upon it by the OECD and Global Forum with respect to be a compliant jurisdiction.

\subsection{Other international tax developments: the HKSAR engaging with BEPS}

The second major international tax development that this paper will review is the HKSAR's engagement with BEPS, focussing on aspects of BEPS outside of AEOI (which are largely addressed by Action Plan 13, key aspects of which have already been discussed in this paper). It should be recognised that AEOI is directly linked to BEPS as both developments include a focus on enhanced transparency, in the context of assisting revenue authorities to address the challenges of cross border taxation. In many ways, AEOI was a necessary interim step to develop some of the foundations for the significant components of BEPS. Thus, BEPS may also be viewed as in part building on the platform of AEOI.

The HKSAR was largely silent on its approach to BEPS, until the Budget 2016-17 speech delivered on 24 February 2016 by the Financial Secretary, Hon John C Tsang, who stated: ${ }^{32}$

Hong Kong is also obliged to implement the project of the Group of Twenty against base erosion and profit shifting. We shall conduct analysis, consult the trade and consider participating in an international framework being developed by the Organisation for Economic Cooperation and Development.

The Financial Secretary also indicated that the HKSAR is committed to modernising its tax legislation to ensure that it maintains a fair tax environment, aligns its tax system with international standards, and enhances its overall competitiveness. Clearly the HKSAR will need to make some

\footnotetext{
${ }^{31}$ See further: Inland Revenue, “Inland Revenue (Amendment) (No. 2) Ordinance 2017 gazetted” (2017) Press Release.

32 See PwC, Hong Kong is embarking on the BEPS journey (2016) May. See also Hon John C Tsang (Financial Secretary), Budget 2016-17 Speech (2016) para 151; available at: http://www.budget.gov.hk/2016/eng/pdf/e_budgetspeech2016-17.pdf (emphasis added).
} 
legislative and practice changes in the not too distant future so as to move towards being "BEPS compliant". Through the HKSAR government becoming an Associate member and its adherence to BEPS, this may be viewed as a mark of the jurisdiction being a responsible global citizenship.

At two relatively recent conferences, the HK Deputy Commissioner of Inland Revenue (CIR) indicated that the HKSAR will be working to introduce a profits tax exemption for offshore funds and a concessionary tax regime for aircraft leasing. ${ }^{33}$ While not significant in themselves, these announcements demonstrate further movement by the HKSAR to engage with the international tax community.

In relation to BEPS, priority is to be given to four BEPS Action Plans ${ }^{34}$ where there are internationally agreed minimum standards, namely: review of harmful tax practices and spontaneous exchange of information on certain tax rulings (Action 5); model tax treaty provisions to prevent treaty abuse (Action 6), CbCR (Action 13) and improvements to cross border tax dispute resolution (Action 14).

A major priority area for the HKSAR is transfer pricing where it is looking to develop comprehensive legislation and documentation requirements (which will need to align with CbCR requirements). This will follow consultation which is scheduled to start in the last part of 2016 . The HKSAR is also looking to ensure it will be able to implement the requirements of Action 15 concerning the introduction of a multilateral instrument. Following approaches from some treaty

${ }^{33}$ See further: 2016 Global Tax Symposium- Asia, which was organised by PWC (April 27-28, 2016); and 2016 Annual Conference organised by the Association of Chartered Certified Accountants (ACCA) (30 April 2016).

34 The OECD's 15 Action Plans comprise:

- Explanatory Statement 2015 Explanatory Statement 2015

- Action 1: Addressing the Tax Challenges of the Digital Economy

- Action 2: Neutralising the Effects of Hybrid Mismatch Arrangements

- Action 3: Designing Effective Controlled Foreign Company Rules

- Action 4: Limiting Base Erosion Involving Interest Deductions and Other Financial Payments

- Action 5: Countering Harmful Tax Practices More Effectively, Taking into Account Transparency and Substance

- Action 6: Preventing the Granting of Treaty Benefits in Inappropriate Circumstances

- Action 7: Preventing the Artificial Avoidance of Permanent Establishment Status

- Actions 8-10: Aligning Transfer Pricing Outcomes with Value Creation

- Action 11: Measuring and Monitoring BEPS

- Action 12: Mandatory Disclosure Rules

- Action 13: Guidance on Transfer Pricing Documentation and Country-by-Country Reporting

- Action 14: Making Dispute Resolution Mechanisms More Effective

- Action 15: Developing a Multilateral Instrument to Modify Bilateral Tax Treaties

See further http://www.oecd.org/ctp/beps-about.htm. 
partners, the HKSAR may introduce a simplified limitation of benefits (LOB) rule and principle purpose test (PPT) as part of its standard CDTA in the future. ${ }^{35}$ Furthermore, with the PRC being a signatory to the Multilateral Convention on Mutual Administrative Assistance in Tax Matters (Multilateral Convention) and specifically extending its application to Hong Kong, then the HKSAR will arguably have obligations and benefits like any other signatory. ${ }^{36}$ The PRC signed on behalf of the HKSAR as the HKSAR could not be a signatory itself given it is not a sovereign state.

However, with the gazetting of the Inland Revenue (Amendment) (No 5) Bill 2017 on 6 October $2017,{ }^{37}$ it is proposed that the Chief Executive will be empowered to give effect to the Multilateral Convention (and potentially other international agreements), along with amendments to align the IRO with the OECD's CRS requirements to remove a number of inconsistences within the IRO. This Amendment Bill provides further evidence of the HKSAR's active engagement with BEPS. Specifically, in the Press release, it states: ${ }^{38}$

"The Chief Executive in Council currently does not have the power under the IRO to give effect to multilateral tax agreements or arrangements for international tax co-operation other than affording relief from double taxation and exchange of information. The Amendment Bill aims to remove the limitation so as to facilitate Hong Kong's participation in multilateral tax agreements and new areas of international tax co-operation."

As part of ANNEX E to this Amendment Bill (reproduced in Table 1 below), the HKSAR sets out how it proposes to 'adopt' the various key Articles within the Multilateral Convention. It is of note that the proposal is to adopt the mandatory provisions and decline to adopt provisions when there is an ability to opt out.

\footnotetext{
${ }^{35}$ The LOB article(s) in a CDTA is designed to eliminate treaty shopping. These LOB articles deny the benefits of the tax treaty to residents that do not meet additional tests or requirements, such as legal nature, ownership, and general activities. The LOB is a specific anti-abuse rule. The PPT is a general ant-abuse rule more akin to a general antiavoidance rule (GAAR).

${ }^{36}$ The PRC signed the multilateral convention on 27 August 2013, with entry into force on1 February 2016. See further: http://www.oecd.org/tax/exchange-of-tax-information/convention-on-mutual-administrative-assistance-in-taxmatters.htm.

${ }^{37}$ Inland Revenue (Amendment) (No 5) Bill 2017.

${ }^{38}$ HKIRD, Inland Revenue Ordinance to be amended to facilitate international tax co-operation (2017) Press Release.
} 
Table 1: Analysis and assessment of the major provisions of the Multilateral Convention

\begin{tabular}{|c|c|c|c|}
\hline \multicolumn{2}{|c|}{ Provision } & \multirow[t]{2}{*}{ Nature } & \multirow[b]{2}{*}{$\begin{array}{l}\text { Analysis and assessment } \\
\text { The minimum types of taxes covered } \\
\text { by the Multilateral Convention } \\
\text { include taxes on income or profits, } \\
\text { taxes on capital gains which are } \\
\text { imposed separately from the tax on } \\
\text { income or profits, and taxes on net } \\
\text { wealth. While the Multilateral } \\
\text { Convention may also cover other } \\
\text { types of taxes, we propose that Hong } \\
\text { Kong would only provide assistance } \\
\text { to the minimum types of taxes above. }\end{array}$} \\
\hline & $\begin{array}{l}\text { Types of taxes covered } \\
\text { (Article 2) }\end{array}$ & & \\
\hline (b) & $\begin{array}{l}\text { Exchange of information on } \\
\text { request (Article 5) }\end{array}$ & Mandatory & $\begin{array}{l}\text { Hong Kong has been handling } \\
\text { exchange of information requests } \\
\text { from our CDTA/TIEA partners and, in } \\
\text { accordance with the OECD's } \\
\text { standard. The scope of information to } \\
\text { be provided under CDTA/TIEA or } \\
\text { under the Multilateral Convention is } \\
\text { the same. We propose that this } \\
\text { mandatory provision should apply to } \\
\text { Hong Kong. }\end{array}$ \\
\hline & $\begin{array}{l}\text { Automatic exchange of } \\
\text { information (Article 6) }\end{array}$ & Mandatory & $\begin{array}{l}\text { Hong Kong has already put in place } \\
\text { the legal framework for implementing } \\
\text { AEOI, and is prepared to expand } \\
\text { AEOI network through the } \\
\text { Multilateral Convention. Hong Kong } \\
\text { can also rely on this provision to take } \\
\text { forward automatic exchange of CbC } \\
\text { reports which is a minimum standard } \\
\text { under the BEPS package. We propose } \\
\text { that this mandatory provision should } \\
\text { apply to Hong Kong. }\end{array}$ \\
\hline & $\begin{array}{l}\text { Spontaneous exchange of } \\
\text { information (Article 7) }\end{array}$ & Mandatory & $\begin{array}{l}\text { While Hong Kong has not conducted } \\
\text { spontaneous exchange of information } \\
\text { with our CDTA/TIEA partners so far, } \\
\text { Hong Kong has undertaken to } \\
\text { exchange information on six types of } \\
\text { tax rulings, under the minimum } \\
\text { standard of the BEPS package, on a } \\
\text { spontaneous basis. Hong Kong can } \\
\text { rely on this provision to take forward } \\
\text { such exchange. We propose that this } \\
\text { mandatory provision should apply to } \\
\text { Hong Kong. }\end{array}$ \\
\hline & $\begin{array}{l}\text { Simultaneous tax } \\
\text { examinations (Article 8) }\end{array}$ & $\begin{array}{l}\text { Mandatory, but it will be up to a party } \\
\text { to decide whether to participate in a } \\
\text { particular examination }\end{array}$ & $\begin{array}{l}\text { Simultaneous tax examination refers } \\
\text { to an arrangement between two or } \\
\text { more jurisdictions, each in its own } \\
\text { territory, to examine tax affairs of } \\
\text { persons in which they have a common } \\
\text { or related interest, with a view to } \\
\text { exchanging any relevant information } \\
\text { which they so obtain. We propose that } \\
\text { Hong Kong, as a general rule, will not } \\
\text { participate in any simultaneous tax } \\
\text { examinations. }\end{array}$ \\
\hline
\end{tabular}




\begin{tabular}{|c|c|c|c|}
\hline & $\begin{array}{l}\text { Tax examinations abroad } \\
\text { (Article 9) }\end{array}$ & $\begin{array}{l}\text { Mandatory provision, but a party can } \\
\text { make a declaration not to accept such } \\
\text { requests as a general rule }\end{array}$ & $\begin{array}{l}\text { Tax examinations abroad refers to an } \\
\text { arrangement which a jurisdiction may } \\
\text { allow the representative from another } \\
\text { jurisdiction, upon the latter's request, } \\
\text { to be present at the appropriate part of } \\
\text { a tax examination in the former's } \\
\text { territory. We propose to declare under } \\
\text { the Multilateral Convention that, as a } \\
\text { general rule, Hong Kong will not } \\
\text { accept such requests. }\end{array}$ \\
\hline (g) & $\begin{array}{l}\text { Assistance in recovery of } \\
\text { taxes (Articles 11-16) }\end{array}$ & Optional & $\begin{array}{l}\text { These provisions refer to the } \\
\text { assistance which a jurisdiction } \\
\text { provides for recovery of taxes that are } \\
\text { charged by another jurisdiction. We } \\
\text { propose that Hong Kong will not } \\
\text { provide such assistance. }\end{array}$ \\
\hline (h) & $\begin{array}{l}\text { Service of documents } \\
\text { (Article 17) }\end{array}$ & Optional & $\begin{array}{l}\text { This provision refers to the assistance } \\
\text { which a jurisdiction provides for } \\
\text { service of documents, including those } \\
\text { relating to judicial decisions, which } \\
\text { relate to a tax covered by the } \\
\text { Multilateral Convention at the request } \\
\text { of another jurisdiction. We propose } \\
\text { that Hong Kong will not provide such } \\
\text { assistance. }\end{array}$ \\
\hline
\end{tabular}

Provisions not listed in the above table are technical and operational in nature, e.g. definitions, how to deal with conflicting information received and language of transmission.

A significant challenge for the HKSAR in embracing BEPS is to revise its existing tax laws to meet the requirements of the international standards set by BEPS without (severely) compromising its simple and low tax regime. This decision by the HKSAR to be actively involved to meet the key principles underlying the BEPS initiatives is also important in maintaining its status as a desirable business location. Big 4 accounting firm EY, state in this regard: ${ }^{39}$

With these BEPS changes (particularly around transparency), there will inevitably be additional burdens placed on taxpayers around reporting and indeed reviewing their operating models to facilitate compliance with the new international standards. However, improving Hong Kong's reputation as an internationally compliant player, particularly in a world now characterized by greater transparency, will likely result in higher benefits or lesser challenges from other tax authorities to businesses who would like to access Hong Kong's simple and attractive tax regime.

What are the implications of BEPS for the HKSAR's tax system? First, BEPS is much more significant in terms of its impact than AEOI and the common reporting standard. BEPS will have a significant impact the application of DTAs, of which the HKSAR is party currently to 45 . It will

39 EY, Hong Kong's OECD BEPS Associate status requires implementation of BEPS minimum standards" (2016) International Tax and TP Alert (June), at 3 (emphasis added). 
also focus more attention on the HKSAR through enhanced transparency, which will place pressure on the HKSAR's approach to protecting the privacy of taxpayer information.

Second, as Mariani observes: ${ }^{40}$

BEPS will furthermore necessitate the implementation of a comprehensive statutory transfer pricing regime in Hong Kong, which should prompt a re-examination of received wisdom on tax-efficient structuring in Hong Kong. To date, transfer pricing in Hong Kong has been governed by a relatively basic and rarely applied statutory provision; however, the Hong Kong Inland Revenue Department has identified the introduction of a BEPS-compliant transfer pricing regime as an area of particularly high priority for legislative reform.

The days of Hong Kong having a simple tax code are over, this practitioner fears, never to return. But, as is often the case with radical legislative reform, there is a first mover advantage to be obtained in being among the first to adapt and respond to the challenges posed by changes in the international tax landscape. That will require greater sophistication in tax planning and the acceptance of the fact that practices that have long gone unchallenged will need to be examined under the lens of BEPS.

Stricter and more comprehensive transfer pricing requirements requires an appropriate balance to be struck between the need for the HKIRD to gather necessary information and to minimise the compliance burden on businesses. Whether the balance that is struck is appropriate will become clearer when the new transfer pricing policy is operational and HKSAR taxpayers are meeting the enhanced documentation requirements and potentially applying for advance pricing agreements (APAs) and/or facing HKIRD audits.

In terms of the status of the HKSAR's BEPS action plan implementation, Table 2 outlines an assessment from Big 4 accounting firm Deloitte, which is supplemented through further analysis by the writer. This analysis has been updated for the release of the recent consultation paper on BEPSrelated items in July $2017:^{41}$

\footnotetext{
40 Stefano Mariani, “Hong Kong’s Simple Tax Code Days Are Over? - The Coming Storm” (Deacons, June 3 2016), emphasis added; available at: http://www.lexology.com/library/detail.aspx?g=85f29bd1-f30e-4dfa-ac83-d1ac9923c5bf.

41 Deloitte, BEPS Actions implementation by country: Hong Kong (September 2016); available at: https:/www2.deloitte.com/content/dam/Deloitte/global/Documents/Tax/dttl-tax-beps-actions-implementation-hongkong.pdf. See also Financial Services and the Treasury Bureau, Consultation Report on Measures to Counter Base Erosion and Profit Shifting (July 2017).
} 
Table 2: The HKSAR's OECD BEPS Readiness

\begin{tabular}{|c|c|c|c|}
\hline Action & $\begin{array}{l}\text { OECD } \\
\text { Categorisation }\end{array}$ & $\begin{array}{l}\text { Notes on local } \quad \text { country } \\
\text { implementation }\end{array}$ & $\begin{array}{l}\text { Expected } \\
\text { timing }\end{array}$ \\
\hline $\begin{array}{l}\text { VAT on business to } \\
\text { customers digital services } \\
\text { (Action } 1)\end{array}$ & $\begin{array}{l}\text { Common } \\
\text { approach }\end{array}$ & $\begin{array}{l}\text { The HKSAR does not impose VAT. The IRD } \\
\text { intends to issue a DIPN on the digital } \\
\text { economy }\end{array}$ & Not yet known \\
\hline Hybrids (Action 2) & $\begin{array}{l}\text { Common } \\
\text { approach }\end{array}$ & $\begin{array}{l}\text { The HKSAR's DIPN on the taxation of hybrid } \\
\text { instruments is not aimed at avoiding double } \\
\text { non-taxation with a treaty country. } \\
\text { The IRD plans to introduce legislation to } \\
\text { address hybrid mismatch arrangements. } \\
\text { Legislation was enacted to clarify tax } \\
\text { treatment of regulatory capital securities } \\
\text { comprising certain hybrid instruments under } \\
\text { Basel III follows that of debt. }\end{array}$ & $\begin{array}{l}\text { Not yet known } \\
\text { Legislation was } \\
\text { passed into law on } \\
26 \text { May } 2016\end{array}$ \\
\hline CFCs (Action 3) & Best practice & $\begin{array}{l}\text { As the HKSAR has a source-based tax system } \\
\text { and does not tax dividends, not specific rules } \\
\text { are expected. }\end{array}$ & N/A \\
\hline $\begin{array}{l}\text { Interest deductions (Action } \\
\text { 4) }\end{array}$ & $\begin{array}{l}\text { Common } \\
\text { approach }\end{array}$ & $\begin{array}{l}\text { The HKSAR has specific rule limiting interest } \\
\text { deductions, especially interest paid to non- } \\
\text { residents. It does not have thin capitalisation } \\
\text { rules. The IRD may review the interest } \\
\text { deduction rules. }\end{array}$ & Not yet known \\
\hline $\begin{array}{l}\text { Harmful tax practices } \\
\text { (Action 5) }\end{array}$ & $\begin{array}{l}\text { Minimum } \\
\text { standard }\end{array}$ & $\begin{array}{l}\text { The IRD will review and amend provisions } \\
\text { found to be harmful, and consider mandatory } \\
\text { spontaneous EOI on certain rulings. }\end{array}$ & Not yet known \\
\hline $\begin{array}{l}\text { Prevent treaty abuse } \\
\text { (Action 6) }\end{array}$ & $\begin{array}{l}\text { Minimum } \\
\text { standard }\end{array}$ & $\begin{array}{l}\text { The IRD will consider whether an applicant } \\
\text { would be entitled to benefits under a treaty } \\
\text { when processing an application for a } \\
\text { certificate of residence. }\end{array}$ & Not yet known \\
\hline $\begin{array}{l}\text { Permanent establishment } \\
\text { status (Action 7) }\end{array}$ & $\begin{array}{l}\text { Revision of } \\
\text { existing standard }\end{array}$ & $\begin{array}{l}\text { The IRD will amend the legislation and issue } \\
\text { a DIPN to provide more guidance. }\end{array}$ & Not yet known \\
\hline $\begin{array}{l}\text { Transfer pricing (Actions 8- } \\
\text { 10) }\end{array}$ & $\begin{array}{l}\text { Revision of } \\
\text { existing standard }\end{array}$ & $\begin{array}{l}\text { The HKSAR has two DIPNs providing } \\
\text { guidance which generally follow OECD } \\
\text { guidelines. Transfer pricing is a high priority } \\
\text { for the IRD, and will consult with the public } \\
\text { and introduce bills to LegCo for review and } \\
\text { approval. The focus area will be the } \\
\text { alignment of profits with economic activities. }\end{array}$ & $\begin{array}{l}\text { Bill yet to be } \\
\text { introduced }\end{array}$ \\
\hline $\begin{array}{l}\text { Measuring and Monitoring } \\
\text { BEPS (Action 11) }\end{array}$ & $\begin{array}{l}\text { Common } \\
\text { approach }\end{array}$ & $\begin{array}{l}\text { The actions taken under } \mathrm{CbC} \text { (Action } 13 \text { ) are } \\
\text { to complement the economic analysis of } \\
\text { BEPS. }\end{array}$ & Ongoing \\
\hline $\begin{array}{l}\text { Disclosure of aggressive tax } \\
\text { planning (Action 12) }\end{array}$ & Best practice & $\begin{array}{l}\text { Legislation on automatic exchange of } \\
\text { financial account information has been } \\
\text { introduced. }\end{array}$ & $\begin{array}{l}\text { This was enacted } \\
\text { with effect from } 30 \\
\text { June } 2016 \text {, with } \\
\text { the first AEOI to } \\
\text { commence by end } \\
\text { of } 2018 \text {. }\end{array}$ \\
\hline $\begin{array}{l}\text { Transfer } \\
\text { documentation \& } \\
\text { (Action 13) }\end{array}$ & $\begin{array}{l}\text { Common } \\
\text { approach }\end{array}$ & $\begin{array}{l}\text { As noted above, transfer pricing is a high } \\
\text { priority with the IRD to review the need to } \\
\text { update current practices, including the revised } \\
\text { documentation approach recommended by the } \\
\text { G20/OECD. } \\
\text { The IRD will consult, introduce bills to LegCo }\end{array}$ & Bill introduced in \\
\hline
\end{tabular}




\begin{tabular}{|c|c|c|c|}
\hline & standard & $\begin{array}{l}\text { for review and approval, and enter into } \\
\text { competent authority agreements for exchange } \\
\text { of CbC reports. } \\
\text { The IRD will require multinationals to provide } \\
\text { high level information on their global business } \\
\text { operations and transfer pricing policies, } \\
\text { transactional transfer pricing documentation } \\
\text { specific to each country and annual CbC } \\
\text { reports for each jurisdiction in which they do } \\
\text { business. }\end{array}$ & October 2017 \\
\hline $\begin{array}{lr}\text { Dispute } & \text { resolution } \\
\text { mechanisms } & \text { effectiveness } \\
\text { (Action 14) } & \end{array}$ & $\begin{array}{l}\text { Common } \\
\text { approach }\end{array}$ & $\begin{array}{l}\text { IRD has indicated that this is one of four } \\
\text { priority areas where there are agreed standards } \\
\text { with which Hong Kong will cooperate. }\end{array}$ & $\begin{array}{l}\text { Bill yet to be } \\
\text { introduced }\end{array}$ \\
\hline $\begin{array}{l}\text { Developing a Multilateral } \\
\text { Instrument to modify } \\
\text { bilateral tax treaties (Action } \\
\text { 15) }\end{array}$ & $\begin{array}{l}\text { Common } \\
\text { approach }\end{array}$ & $\begin{array}{l}\text { The HKSAR is looking to ensure it will be } \\
\text { able to implement the requirements of this } \\
\text { action plan. }\end{array}$ & $\begin{array}{l}\text { Bill yet to be } \\
\text { introduced }\end{array}$ \\
\hline
\end{tabular}

Another aspect associated with BEPS that will impact on the HKSAR is intra-group financing arrangements which will form part of the transfer pricing Master file under $\mathrm{CbCR} .{ }^{42}$ With an enhanced focus on information transparency, clearly intra-group financing arrangements will need to be well documented and properly supported. The HKSAR promotes itself as a potential regional treasury hub and has introduced tax incentives for corporate treasury centres; as a consequence of BEPS this aspect will need to be closely reviewed.

Turning to look more closely at recent legislative developments, on 26 October 2016, the HKSAR Government released its consultation paper on measures related to BEPS. ${ }^{43}$ The consultation paper reiterates the HKSAR Government's commitment to implementing BEPS, including the four minimum standards. The HKSAR's priority is to put in place a legislative framework for transfer pricing rulings that meet the latest guidance from the OECD, spontaneous exchange of information (EOI) on tax rulings, $\mathrm{CbCR}$, and cross-border dispute resolution mechanism. ${ }^{44}$ With other BEPs Actions, the HKSAR will monitor international developments, and hence will be a follower.

Importantly, a fundamental transfer pricing rule will be implemented to enable the Commissioner to adjust the profits and losses of businesses. This is a key aspects of BEPS. Penalties to encourage compliance will be introduced. The HKIRD is also working on implementing an advance pricing

\footnotetext{
42 See further KPMG, Hong Kong: Incentives for intra-group financing activities, corporate treasury centres (30 September 2016); available at: https://home.kpmg.com/xx/en/home/insights/2016/09/tnf-hong-kong-incentives-for-intragroup-financing-activities-corporate-treasury-centres.html. See also, EY, "Hong Kong releases new practice note on corporate treasury centers and interest deductibility" (September 2016) Global Tax Alert; at http://www.ey.com/gl/en/services/tax/international-tax/alert--hong-kong-releases-new-practice-note-on-corporatetreasury-centers-and-interest-deductibility.

${ }^{43}$ HKSAR Government, Consultation Paper on measures to counter Base Erosion \& Profit Shifting (October 2016).

${ }^{44}$ See further note 43 , Chapter 2.
} 
agreement (APA) regime to support this new fundamental transfer pricing rule. ${ }^{45}$ This will be essential in assisting MNEs and those with cross-border transactions to utilise transfer pricing methodology that is acceptable to the HKIRD and potentially other jurisdictions.

With respect to CbCR, the OECD's templates will be adopted, with a number of exemptions introduced to reduce the costs for some businesses. It expected that through using the EUR750 million (HK\$6.8 billion) threshold for CbCR, about $150 \mathrm{HKSAR}$ enterprises will need to meet the CbCR requirements. These $\mathrm{CbC}$ reports are to be exchanged automatically between tax administrations under qualifying competent authority agreements (QCAAs). This means only those jurisdictions that have a CDTA or TIEA, or have signed the Multilateral Convention, will be able to exchange reports with the HKSAR. There will also need to be a Competent Authority agreement entered into between the HKSAR and the other jurisdiction for CbCR to operate. MNEs will need to gather information in 2018 and file their first CbC reports to the HKIRD in $2019 .{ }^{46}$

On 22 December 2016, the HKIRD announced that it will accept voluntary filing of CbCR for taxpayers with ultimate parent entities (UPE) located in the HKSAR. ${ }^{47}$ The $\mathrm{CbC}$ report will require aggregate tax jurisdiction-wide information relating to the global allocation of the income, the taxes paid, and certain indicators of the location of economic activity among tax jurisdictions in which the MNE operates. The $\mathrm{CbC}$ report also requires a listing of all the constituent entities for which financial information is reported, including the jurisdiction of incorporation of each of the integral entities (if different from the jurisdiction of tax residence) and the main business activities carried out by that entity. Voluntary filings will cover accounting periods commencing between 1 January 2016 and 31 December 2017, with the necessary procedures expected to be determined in the first quarter of 2017. Transitional arrangements will be put in place.

The multilateral instrument is expected to work without any technical difficulties when applied to the HKSAR's CDTAs. The HKSAR has indicated that it is likely to adopt the principle purpose test as its preferred option in updating its CDTAs. ${ }^{48}$ The HKSAR intends to introduce a statutory mechanism to ensure timely, effective and efficient resolution of cross-border treaty-related disputes. Most of the HKSAR's CDTAs incorporate the mutual agreement procedure (MAP). ${ }^{49}$

\footnotetext{
${ }^{45}$ See further note 48, Chapter 3.

${ }^{46}$ See further note 48 , Chapter 4.

${ }^{47}$ See HKSAR IRD, Country-by-Country Reporting (December 2016); at http://www.ird.gov.hk/eng/tax/dta_cbc.htm.

${ }^{48}$ See further note 48, Chapter 5.

${ }^{49}$ See further note 48 , Chapter 6 . This is an area that will require further legislative amendments under BEPS Action 14.
} 
With respect to spontaneous EOI on tax rulings, the HKSAR will include six categories of rulings within this framework: ${ }^{50}$

1. rulings relating to preferential regimes;

2. unilateral APAs and any other cross-border unilateral rulings in respect of transfer pricing;

3. cross-border rulings providing for a downward adjustment of taxable profits;

4. permanent establishment ruling;

5. related party conduit ruling; and

6. any other type of ruling that, in the absence of spontaneous information exchange, could give rise to BEPS concerns.

This framework would apply to both past and future rulings, and would be underpinned by the HKSAR's CDTAs and TIEAs, with exchange to be on a bilateral basis. The HKSAR is also intending to enhance its tax credit system, ensuring that: ${ }^{51}$

1. the CDTAs prevail over any provision in the Inland Revenue Ordinance;

2. the period for claiming a credit be extended to 6 years;

3. the tax credit be a form of last resort;

4. taxpayers must notify the HKIRD of any adjustments to foreign tax payments; and

5. a credit will not be granted if the taxpayer receives unilateral relief.

The Hong Kong Financial Services Council (HKFSC) issued a discussion paper in December 2016, in which the HKFSC acknowledges that BEPS could have a significant impact on the choice of origin and trading jurisdiction. This is premised on the BEPS principle of recoding profits where value is created. In this regard ${ }^{52}$ :

"BEPS would therefore be especially relevant to Hong Kong based origination and trading entities in relation to the way they are funded, what these entities do for other members of the

\footnotetext{
${ }^{50}$ See further note 48 , Chapter 6.

${ }^{51}$ See further note 48 , Chapter 6.

${ }^{52}$ Hong Kong Financial Services Council, A Paper on Tax Issues Affecting Hong Kong to Become a Preferred Location for Regional and International Financial Institutions to Originate and Trade International Financial Products, FSDC paper No. 26, (December 2016), at 11.
} 
group vis-a-vis clients in other locations and the substance, capital and risks of the origination and trading entities residing in Hong Kong."

As noted earlier in the paper, the FSTB released a consultation report on the HKSAR's approach to implementing BEPS. ${ }^{53}$ Specifically this report addresses: the transfer pricing regulatory regime; transfer pricing documentation and CbCR; the Multilateral Instrument; and other related matters. It also outlines the legislative implementation process. The major changes are anticipated to be with respect to incorporating the OECD's transfer pricing guidelines into HKSAR law. The legislation will confirm the HKSAR's adoption of the CbCR requirements, with some further exceptions to reduce the number of entities needing to comply. The HKSAR will look to introduce the multilateral instruments requirements in a separate bill in 2018.

In their review of the FSTB's response to BEPS, EY observe: ${ }^{.4}$

The Consultation Report shows that positive modifications were made to the Government's BEPS proposals in response to the consultation process. For example, transfer pricing documentation thresholds were revised to appropriately capture target groups and reduce the compliance burden. In addition, clarity was provided in the area of domestic transactions (which will be covered within the scope of the transfer pricing rules), the penalty regime, the application of the fundamental rule to IP and loan transactions, the APA, and the documentation structure. The IRD's announcement of releasing DIPNs will further aid with the application of the transfer pricing rules, and providing certainty to the taxpayers. However, there are certain areas that the IRD has not fully addressed. For example, although the IRD has recognized the comments provided on the interaction of Hong Kong's territorial-based tax regime with transfer pricing principles and the contemporaneous nature and effective date of transfer pricing documentation, the Consultation Paper does not provide further clarity on these points.

Further, the Government also clarified its position regarding the non-acceptance of the LOB. However, shortcomings remain present, such as the absence of detailed guidance on the application of the PPT.

Furthermore, on 31 July 2017, the FSTB released report on the outcome of consultation concerning how the HKSAR will implement the OECD's BEPS recommendations. ${ }^{55}$ Further developments are

\footnotetext{
${ }^{53}$ See FSTB, above note 45.

${ }^{54}$ EY, "Hong Kong releases Consultation Report on Measures to Counter Base Erosion and Profit Shifting" (2017) Global Tax Alert (4 August 2017), emphasis added. See also: Bei Xi Xu, "BEPS Legislation Expected by Year-End" (2017) Tax Notes International (August 7) 532.
} 
expected with respect to the HKSAR's embracing of BEPS over the coming months, including tabling of draft legislation possibly by the end of 2017 (or early 2018), and for the multilateral instrument in 2018. The HKSAR is expected to continue to seek to negotiate CDTAs and TIEAs over the coming months. The major driver will continue to be the G20/OECD's agenda to ensure jurisdictions are ready to implement the necessary changes to ensure relevant standards are in place and best practice is followed in jurisdictions committed to BEPS implementation.

\subsection{Concluding Observations}

Much has happened in the last four years in the HKSAR with respect to tax transparency and exchange of information, as well as embracing the expectations of BEPS implementation. This commenced with the Global Forum releasing its Phase Two Peer Review Report on the HKSAR in November 2013. This report signalled that the HKSAR was largely compliant with its domestic law and regulations with respect to facilitating tax transparency and exchange of information (in a preAEOI environment). A further significant event was the HKSAR concluding an in-substance Model 2 IGA under FATCA that took effect in time for the 1 July 2014 implementation date of FATCA. This was followed up by the HKSAR signing a Model 2 IGA later in 2014.

In the area of "business as usual", TIEAs and CDTAs have continued to be negotiated by the HKSAR, bringing the combined total of CDTAs and TIEAs to 45 as at July 2017, with 2 further agreements having been signed. The writer would suggest that a focus on these activities, along with working towards implementing AEOI, assisted the HKSAR in being removed from the EU's blacklist of non-cooperative jurisdictions in October 2015.

Importantly, AEOI became a reality for the HKSAR from 30 June 2016 with the enactment of an amendment to the IRO. Financial institutions and account holders need to prepare for the verification and collection of information during 2017 so as to be ready to provide information to the HK IRD for the first information exchange via CbCR to other jurisdictions in 2018. This was enhanced by the Inland Revenue (Amendment) (No. 2) Ordinance 2017 that facilitates AEOI to minimise compliance costs and by increasing the number of reportable jurisdictions. Through the PRC signing the Multilateral Convention both on its own behalf and on that of the HKSAR, the HKSAR appeared to become a party to its first major multilateral tax agreement. Any remaining doubt will be resolved with the future enactment of the Inland Revenue (Amendment) (No 5) Bill 2017 which was gazetted on 6 October 2017.

${ }^{55}$ See note 45 . 
Having adopted AEOI and following comments made in Budget 2016, the HKSAR became much more active from June 2016 with respect to the implications of the final Actions under BEPS. This commenced with the public announcement that the HKSAR was formally joining the BEPS implementation nations as an Associate "Hong Kong, China". This means that the HKSAR would work cooperatively with the G20/OECD implement BEPS and develop standards. This commitment covers not only meeting the minimum standards in the four areas of treaty shopping, CbCR, harmful tax practices, and dispute resolution, but also addressing all other relevant BEPS Action Plans. The HKSAR is also supporting voluntary $\mathrm{CbC}$ reporting. If this is not sufficient evidence of the HKSAR's active engagement with BEPS, then the consultation report released on 31 July 2017 detailing the HKSAR's response to adopting key BEPS initiatives and legislating for their implementation should leave one without any doubt.

The analysis set out in this paper indicates that the HKSAR has become an active player in facilitating the objectives of the BEPS action plans. It also suggest there will continue to be significant activity led by the HK IRD and LegCo over the next few years, including a sizeable amount of consultation activity with the public, so as to bring the BEPS initiatives to fruition within the HKSAR. In the writer's view, the HKSAR has evolved from being a reluctant and slow follower to implement exchange of information beyond that of the CDTA, to a jurisdiction that is willing to meet minimum international expectations with respect to AEOI. It has also been proactive in its involvement in BEPS, such as being part of the Ad hoc Group that developed a multilateral instrument to modify bilateral tax treaties as part of BEPS Action 15. Most recently, its decision to empower the Chief Executive to give effect to the Multilateral Convention (and potentially other international agreements), along with amendments to align the IRO with the OECD's CRS requirements, are evidence of active engagement with BEPS.

In this paper, the writer argues that the implementation of BEPS will have a significant impact on the HKSAR's tax system, building upon the earlier critical foundation of implementation AEOI, and the more recent amendment to the IRO that facilitates the practical application of AEOI through a significant increase in reportable jurisdictions. Compared to AEOI, BEPS is much more significant in terms of its impact, including the content and application of DTAs, of which the HKSAR is currently a party to 45. A critical re-examination and, where necessary, re-organisation of international tax structures operating with a HKSAR nexus needs to be undertaken. The days of the HKSAR having a simple tax code are arguably over, at least with respect to taxpayers having crossborder transactions. Greater sophistication in tax planning will be needed, along with greater scrutiny using the lens of BEPS. 
